\title{
Ympäristöinnostaja luontokokemusten ja ekososiaalisesti merkittävien suhteiden välittäjänä
}

Satu Järvinen, Raisa Foster ja Nicholas Morris

\section{TIIVISTELMÄ}

Artikkelissa luonnostellaan laaja-alaisesti eri kasvatuskonteksteihin soveltuvan ympäristöinnostamisen lähtökohtia, periaatteita ja tavoitteita. Tarve ympäristöinnostamisen käsitteellistämiselle nousi Ohiossa toteutetun Arts for Parks -hankkeen myötä. Ohiolaisten ympäristökasvattajien haastatteluiden ja työpajahavainnointien analysointi nosti keskeisimpinä piirteinä esiin kasvattajan omista kokemuksista nousevan vastuullisen luontosuhteen sekä heidän syvän luontorakkautensa ja innostuksensa tiedon jakamiseen ja kokemusten tarjoamiseen. Sosiokulttuurisen innostamisen teoriaan nojaten ympäristöinnostamisen lähtökohdiksi voidaan asettaa toiminnan paikkasidonnaisuus ja innostajan henkilökohtainen työote. Ympäristöinnostajan keskeisenä tehtävänä on ekososiaalisesti merkittävien suhteiden välittäminen. Ympäristöinnostamisella pyritään emansipaatioon kestämättömyyttä tuottavista arvoista, uskomuksista ja toimintatavoista. Ympäristöinnostaminen on siis yhteisöllistä toimintaa kohti ekologisesti ja sosiaalisesti kestävämpää tulevaisuutta.

Avainsanat: ekososiaalinen sivistys, emansipaatio, kokemuksellisuus, luontosuhde, rakkaus, sosiokulttuurinen innostaminen 


\section{ABSTRACT \\ ENVIRONMENTAL ANIMATEUR AS AN INTERPRETER OF NATURE EXPERIENCES AND ECOSOCIALLY SIGNIFICANT RELATIONSHIPS}

- The article outlines the starting points, principles and goals of environmental animateuring suitable for different educational contexts. The need to conceptualize environmental animateuring was born in the Arts for Parks project in Ohio. The interviews of environmental educators and the observations of workshops brought up the essential characteristics, such as the responsible nature connection arising from the educator's own experiences, their deep love of nature and enthusiasm for sharing information and providing experiences to others. On this basis, and based on the theories of sociocultural animation, we propose that environmental animateuring should start from a place-based and personal approach. The central task of an animateur is to work as an interpreter of ecosocially significant relationships. The goal is to emancipate people from their unsustainable values, beliefs, and practices. Environmental animateuring is community action towards a more ecologically and socially sustainable future.

Keywords: ecosocial approach, emancipation, experience, love, nature connectedness, sociocultural animation

\section{Johdanto}

— kologinen kriisi on tässä ja nyt. Elämme ajassa, jossa uutisvirran täyttä— vät toinen toistaan vaikeammat aiheet, kuten ilmastonmuutos, kuudes sukupuuttoaalto, napajäätiköiden sulaminen ja valtavat metsäpalot sekä ihmisryhmien välinen polarisaatio. Uutena globaalina koettelemuksena olemme kohdanneet merkittävästi perusturvallisuuden tunnetta horjuttavan koronaviruspandemian. Globaalit ongelmat ovat monisyisiä ja pelottavia, ja siksi ne herättävät ahdistusta ja torjuntaa. Maapallon ekologinen perusta horjuu, mutta kaikesta tiedosta huolimatta ihmiskunta ei aktivoidu tekemään muutoksia. Miksemme pysty muuttamaan maapallolle ja elämän jatkuvuudelle haitalliseksi todistettuja toimintatapoja?

Monitieteinen ekokriisiin liittyvä tutkimus on viime vuosina lisääntynyt voimakkaasti myös kasvatustieteen kentällä (Foster 2017; Foster, Salonen \& Keto 2019; Salonen 2014; Suominen 2016; Värri 2018). Suomalaisessa ympäristökasvatuksen tutkimuksessa on viime aikoina nostettu esille muun muassa ilmastokasvatusta (Cantell, Tolppanen, Aarnio-Linnanvuori \& Lehtonen 2019), ympäristövastuuta (Aarnio-Linnanvuori 2019) 
ja ympäristötunteita (Pihkala 2017). Ympäristökasvatuksesta on julkaistu myös kattavia käsikirjoja (Cantell 2004; Cantell, Aarnio-Linnanvuori \& Tani 2020; Parikka-Nihti \& Suomela 2014). Sosiaalipedagogiikan piirissä keskustelu ekologisesta ulottuvuudesta on pitkään jäänyt marginaaliin, mutta nyt se on hiljalleen nousemassa esiin (Nivala \& Ryynänen 2019, 299). Koska ekologinen kriisi on tunnustetusti ihmisen aiheuttama, on tärkeätä vaikuttaa erityisesti ihmisten arvoihin ja asenteisiin. Vaikuttaminen taas tapahtuu keskeisesti suunnitelmallisen kasvatuksen kautta. Toisin sanoen ekokriisistä ja sen ratkaisuista puhuttaessa luonnontieteellinen näkökulma ei yksinään riitä, vaan sen rinnalle on nostettava ihmistieteellistä ympäristötutkimusta sekä kehitettävä ihmisestä itsestään lähtevään ekologiseen muutokseen pyrkiviä kasvatuskäytäntöjä (Foster 2016, 166). Kasvatus- ja sosialisaatioinstituutiot ovat osa sekä ekokriisin haasteita että ratkaisuja - siksi olisi hyvä pohtia uudelleen niiden tehtävää suhteessa vallitsevaan tilanteeseen (Värri 2018, 12).

Perinteisten kasvatus- ja sosialisaatiomallien ja vallitsevan todellisuuden välillä ilmenevään epätasapainoon on mahdollista vaikuttaa esimerkiksi sosiokulttuurisella innostamisella (Kurki 2000, 13). Ekokriisin aikana sosiokulttuurinen lähestymistapa ei kuitenkaan yksin riitä, vaan sosiaalisen ja kulttuurisen kontekstin tunnistamisen lisäksi tarvitaan sen tosiasian tunnustamista, että ihminen on keskeisesti riippuvainen myös "enemmän kuin ihmisen maailmasta" (more-than-human world, Abram 1996) eli toisin sanoen toimivista ekosysteemeistä ja planetaarisista suhteista (Foster ym. 2019; Salonen 2014; Värri 2018).

Artikkelin tavoitteena on luonnostella ympäristöinnostamisen lähtökohtia eli sen taustafilosofiaa, periaatteita ja tavoitteita. Hahmottelemamme lähtökohdat pohjautuvat sekä sosiokulttuurisen innostamisen (Foster 2012; 2015; 2016; Kurki 2000; 2005; 2010; Nivala \& Ryynänen 2019) että ekososiaalisen kasvatuksen (Foster ym. 2019; Martusewicz, Edmundson \& Lupinacci 2015; Salonen 2014; Värri 2018) teorioihin. Havahduimme ympäristöinnostamisen käsitteellistämisen tarpeeseen Ohiossa toteuttamamme Arts for Parks -hankkeen (2016-2017) myötä. Esittelemme hahmottelemiamme ympäristöinnostamisen lähtökohtia, jotka soveltuvat erilaisiin kasvatuskonteksteihin.

Pyrimme ympäristöinnostamisen taustafilosofian luonnostelun kautta tarjoamaan laaja-alaiselle ympäristökasvatuksen kentälle sosiaalipedagogiikan tiedeperustasta ja erityisesti sen kriittisestä perinteestä nousevan näkökulman. Toisin sanoen kasvatuksellisen ja ekologisen näkökulman 
lisäksi korostamme sosiaalisen ja kulttuurisen ulottuvuuden tunnistamisen merkitystä ympäristöinnostamisessa. Vaikka ekososiaaliset haasteet ovat globaaleja, on ratkaisuja ekokriisiin etsittävä nimenomaan paikallisen yhteisön ja ympäristön kollektiivisen ymmärtämisen ja toiminnan kautta. Artikkelissa hahmottelemamme ympäristöinnostamisen idea voi tarjota kehyksen ympäristökasvatuksen toimintatapojen kehittämiselle erilaisissa toimintaympäristöissä.

\section{Ekokriisi ja kasvatus}

Ekokriisin myötä olemme ihmiskuntana vähintään yhtä isojen mullistusten edessä kuin maailmansotien aikana. Ekologisista ongelmista on seurannut myös monenlaisia sosiaalisia haasteita (Martusewicz ym. 2015). Kun yhä isompi osa maapallon pinta-alasta muuttuu asuinkelvottomaksi, on ilmastopakolaisuuden lisääntyminen kiistämätön tosiasia lähitulevaisuudessa (Piguet 2013). Väestönkasvu ja tuloerojen kasvaminen entisestään lisää väkivaltaisuuksia ja taisteluja niukkenevista resursseista (Homer-Dixon 2006). Ekokriisiä voisi pikemminkin kuvata ihmisyyden kriisiksi, sillä ihminen ei näytä sopeutuneen elämään rajallisella planeetalla (Plumwood 2002, 15).

Ekokriisin torjuminen on vaikeaa, koska muutoksia täytyisi tehdä nopeasti, eivätkä pienet kurssinkorjaukset riitä. Tarvitaan isompaa arvopohjan muutosta, mikä on haastavaa, sillä toisinnamme kasvatuksen ja koulutuksen kautta rajattoman kasvun ihannetta rajallisella planeetallamme (Värri 2018, 45). Tutkijat ovat huomanneet muun muassa edistyksen ideaalille perustuvan elämäntapamme kietoutuneen erottamattomasti myös pedagogiseen ajatteluumme (Jokisaari 2014; Saari 2016; Salonen \& Bardy 2015; Värri 2018).

Kasvatusfilosofi Veli-Matti Värri (2007; 2018) nostaa yhdeksi tärkeimmistä nykyajan kasvatuspäämääristä vastuullisen luontosuhteen. Eettisen luontosuhteen tulee Värrin $(2018,63)$ mukaan olla koko yhteiskunnallisen olemisemme perusta. Ihmisten luontosuhdetta leimaa kuitenkin nykypäivänä käsitys luonnosta lähinnä kulutuksen kohteena, elämysten mahdollistajana ja eräänlaisena ympäristöpalveluiden tuottajana (Valkonen 2013, 5). Filosofi Arnold Berleant (2006, 94-95) kuvaakin länsimaisen kulttuurin käsittävän luonnon jonakin ihmisestä irrallisena, vieraana ja vaarallisena kohteena, joka pitää valloittaa ja valjastaa järjen ja voiman avulla palvelemaan vain ihmistä (myös Plumwood 2002). Luontosuhteemme on siis hyvin ihmiskeskeinen (Värri 2018, 14). 
Tiedämme, että elintapamme tuhoaa maapallon elämää kiihtyvällä tahdilla, mutta lisääntyvä tieto ei tunnu synnyttävän muutosta käytöksessämme. Pyrkimystä kestävämmän tulevaisuuden rakentamiseen kuitenkin on. Esimerkiksi valtakunnallisissa perusopetuksen ja lukion opetussuunnitelmissa sekä varhaiskasvatuksen perusteissa kiinnitetään jo nyt huomiota ekologisten ja sosiaalisten haasteiden yhteenkietoutumiseen (Foster ym. 2019). Opetussuunnitelmissa käytetään käsitettä ekososiaalinen sivistys, kun esitellään kestävän hyvinvoinnin tärkeyttä niin oppilaan henkilökohtaisen kasvun kuin ympäristönkin kannalta. Ekososiaalinen sivistys sisältää ajatuksen arvohierarkian kääntämisestä (Salonen 2014; Salonen \& Konkka 2015): Tärkeimpänä arvona elämän jatkuvuuden kannalta tulisi ymmärtää ekologinen kestävyys. Toisena tulee sosiaalinen kestävyys, joka tarkoittaa ihmisoikeuksien jakamatonta arvoa. Vasta kolmantena arvona pitäisi tarkastella taloudellisia arvoja, sillä talous on vain väline ekologisen ja sosiaalisen kestävyyden saavuttamiseksi. Ekososiaalinen sivistys tarkoittaa, että ihminen sisäistää olevansa erottamattomasti yhteydessä muuhun elämään (Foster ym. 2019; Martusewicz ym. 2015; Salonen 2014; Värri 2018).

Arts for Parks -kehittämishanke toteutettiin yhdysvaltalaisessa kontekstissa. Pohjois-Amerikassa ympäristökasvatusta onkin toteutettu jo pitkään (Carter \& Simmons 2010). Voimakkaammin kaupungistuneessa yhteiskunnassa elävän yhdysvaltalaisen luontosuhde (Louv 2005) on suomalaisiin nähden erilainen, ja siksi luontosuhteen vahvistamiseen pyrkivällä ympäristökasvatuksella on Yhdysvalloissa perusteltu tehtävä. Suomessa jokamiehenoikeudet sekä kaupunkien pienuus mahdollistavat - ainakin teoriassa - jokaisen Suomessa asuvan pääsyn helposti lähimetsään. Yhdysvalloissa luonnonympäristössä oleilu edellyttää maanomistajan luvan, ja siksi ympäristökasvatus tapahtuu siellä usein yksityisen tai julkisen organisaation omistamassa puistossa. Pohjoisamerikkalaisessa ympäristökasvatuksessa keskeistä onkin paikkaperustaisuus (Kudryavtsev, Stedman \& Krasny 2012; Woodhouse \& Knapp 2000) ja yhteisön ymmärtäminen (Andrews, Stevens \& Wise 2002).

Yhdysvaltalaista ympäristökasvatusta on kritisoitu pinnallisuudesta sekä siitä, että se ei huomioi ympäristökysymysten kulttuurisia juuria (Martusewicz ym. 2015, 13). Erityisesti koulujen kanssa toteutettava ympäristökasvatus perustuu edelleen vahvasti vain luonnontieteelliseen näkemykseen ympäristöstä (Stevenson 2007). Vaarana on, että ympäristökasvatusta toteutetaan vain irrallisina tempauksina (Matthies 2001, 36), 
jotka tuottavat ohikiitäviä elämyksiä ja joista ei synny syvällistä, aiemman kokemusperustan päälle rakentuvaa ymmärrystä (Alhanen 2013, 7). Yhdysvaltalainen ympäristökasvatus on myös hyvin yksilökeskeistä, jolloin ongelmien sosiaaliset, poliittiset, kulttuuriset ja taloudelliset syyt jäävät usein huomioimatta (Martusewicz ym. 2015, 14).

\section{Sosiokulttuurinen innostaminen}

Sosiokulttuurinen innostaminen ammentaa tiedeperustansa sosiaalipedagogiikasta ja erityisesti sen kriittisestä perinteestä. Se sisältää kasvatuksellisen näkökulman lisäksi sosiaalisen ja kulttuurisen ulottuvuuden. Kasvatuksellisen toiminnan kautta pyritään tukemaan oman vastuun ja arvojen tiedostamista sekä yksilön kriittisen ajattelun kehittymistä. Sosiaalinen ulottuvuus taas viittaa yhteisön todellisuuden tunnistamiseen ja kehittämiseen. Kulttuurinen näkökulma painottaa luovuuden ja ilmaisun kehittymistä, esimerkiksi omaehtoinen taiteen tekeminen on tyypillinen innostamisen aktiviteetti. Innostaja on ensisijaisesti kasvattaja, joka toimii innostamisen kasvatuksellisen, sosiaalisen, kulttuurisen ja ekologisen ulottuvuuden yhdistäjänä. (Kurki 2000; 2005; 2010; Nivala \& Ryynänen 2019.)

Sosiaalipedagogiikan, ja siten myös sosiokulttuurisen innostamisen, avulla voidaan vastata kasvatus- ja koulutusjärjestelmien ja nyky-yhteiskunnan todellisuuden välillä vallitsevaan epätasapainoon (Kurki 2000, 13; Nivala \& Ryynänen 2019, 300). Innostamisen juuret pohjautuvat toisen maailmansodan jälkeiseen länsimaisen sivilisaation kriisiin, jossa yhteiskunnan oman sisäisen tarpeen kautta on muodostunut innostamisen kulttuuri (Kurki 2000, 13). Meidän ajassamme suurimman kulttuurisen muutostarpeen aiheuttaja on ekologinen kriisi (Foster ym. 2019; Salonen 2014; Värri 2018).

Innostamisen keskeinen tavoite on saada ihmiset tulemaan tietoisiksi roolistaan yhteisöissään ja yhteiskunnassaan - sekä koko planeetalla. Toisin sanoen ihmisten tulee tunnistaa omien valintojensa ja toimintansa kytkeytyminen laajempaan yhteisölliseen ja yhteiskunnalliseen toimintaan sekä niihin erottamattomasti kietoutuvaan ekologiseen ulottuvuuteen. Innostamiseen liittyy keskeisesti tietoiseksi tuleminen, mutta ennen kaikkea innostaminen voidaan ymmärtää kaikkien sellaisten toimintojen yhdistelmänä, jotka luovat yhteisössä osallistumisen prosesseja (Kurki 2000, 26; Nivala \& Ryynänen 2019, 205) ja joiden kautta ihmiset voivat 
potentiaalisesti kasvaa toimijoiksi myös laajemmassa ekososiaalisessa kontekstissa.

Innostaminen on keskeisesti "yhteisöjen kehittämistä" (Nivala \& Ryynänen 2019, 205). Innostamisen kautta vahvistetaan siis ihmisten yhteenkuuluvuudentunnetta omissa yhteisöissään, ja sitä kautta luodaan myös toimintaa yhteisten sosiaalisten - mutta nähdäksemme myös ekologisten - ongelmien ratkaisemiseen (Kurki 2005, 335). Koska konfliktien ratkominen valtiollisella saati globaalilla tasolla on liki mahdotonta, on keskityttävä ruohonjuuritasoon ja ratkaisujen löytämiseen nimenomaan omassa lähiyhteisössä (Pohjakallio 2016, 66). Innostaminen vastaa tähän haasteeseen pureutumalla juuri ryhmien ja yhteisöjen kokemuksiin sekä ihmisten aktivoimiseen paremman elinpiirin luomiseksi (Kurki 2005, 344). Tiivistäen innostaminen voidaan nähdä osallistumisen prosesseja synnyttävien toimintojen yhdistelmänä, joiden myötä ihmiset voivat herkistyä ja motivoitua toimimaan yhteisönsä puolesta (Kurki 2000, 19).

Innostajan persoona ja henkilökohtaiset sitoumukset eli ne ilmiöt, tunteet ja ajatukset, joita kasvattaja pitää merkityksellisinä, vaikuttavat väistämättä hänen toteuttamansa toiminnan taustalla (Kurki 2000, 20). Tämän vuoksi innostajalta vaaditaan hyvää itsetuntemusta, joka auttaa häntä kehittymään tasapainoiseksi ja haastavistakin tilanteista selviäväksi kasvattajaksi (Kurki 2000, 83). Vaikka innostamista tehdään innostajan persoonasta käsin, hän ei ole toiminnan johtaja ja suorittaja, vaan ainoastaan sen alullepanija ja organisoija (Nivala \& Ryynänen 2019, 206).

Innostajaa kuvataan usein välittäjäksi, joka auttaa sosiaalisten suhteiden luomisessa sekä yhdistää ihmisiä yhteisöihinsä ja myös laajemmin yhteiskuntaan (Kurki 2000, 23-24; 2010, 190). Sitoutuminen yhteisöön syntyy tyypillisesti yhteisen toiminnan kautta ja tilanteessa, jossa ihmiset kokevat toimivansa yhteisen päämäärän hyväksi ja huomaavat myös oman merkityksensä osana laajempaa kokonaisuutta (Foster 2012, 223; Nivala \& Ryynänen 2019, 206). Innostamisen toimintaa ja sen lopputulosta ei voi koskaan päättää valmiiksi etukäteen, koska prosessi rakentuu aina innostamisen projektissa yhdessä innostettavien kanssa (Foster 2012, 2526). On tärkeätä, että innostaja tunnistaa sen todellisuuden, missä yhteisö elää, ja asettaa tältä pohjalta yhdessä osallistujien kanssa innostamisen toiminnalle tavoitteet. Innostamisen projekteissa korostuu toimintatutkimuksellinen ote (Nivala \& Ryynänen 2019, 205) ja yhteisöllisen tiedon saavuttaminen (Kurki 2000, 31-32). 


\section{Arts for Parks -hanke}

Tämä tutkimus sai alkunsa Arts for Parks -kehittämishankkeesta, jonka toteutimme Ohiossa kesällä 2017. Osana hanketta keräsimme puolistrukturoitujen teemahaastatteluiden avulla paikallisten ympäristökasvattajien ajatuksia heidän tekemästään kasvatustyöstä ohiolaisissa puisto-organisaatioissa. Lisäksi havainnoimme ympäristökasvattajien työpajoja. Toteutimme Arts for Parks -hankkeen osana Art-Eco-tutkimushanketta ${ }^{1}$. Kansainvälisen tutkimushankkeen aikana tapahtuneet vierailut, keskustelut ja kohtaamiset - eli käytännön havainnoista syntyneet kysymykset - ovat sosiokulttuurisen innostamisen teorian ohella vaikuttaneet siihen, miten luonnostelemme tässä artikkelissa ympäristöinnostamisen lähtökohtia. Toisin sanoen tutkimuksemme sijoittuu käytännön ja teorian välimaastoon molemmista ammentaen ja molempia täydentäen (Stage \& Dannels 2000), mikä on tyypillistä sosiaalipedagogiselle tutkimukselle (Nivala \& Ryynänen 2019, 19).

Yhdysvaltalaisissa puistoissa on jo useiden vuosikymmenten ajan tuotu taideteoksia luonnonympäristöihin Arts in the Parks (NPS 2020) -ohjelman kautta. Taide on kuitenkin jäänyt tällöin helposti vain irralliseksi koristeeksi, kuin "ulkoilmamuseoksi", eikä taiteen kautta ole välttämättä edes pyritty haastamaan esimerkiksi vallitsevia valtasuhteita ihmisen ja muun luonnon välillä. Vaikka taidetta ja muita kokemuksellisen oppimisen tapoja saatetaan käyttää ympäristökasvatuksen ohjelmissa osana oppimisprosessia, taide nähdään usein lähinnä välineenä, sen sijaan että sillä olisi itseisarvo (ks. myös Sava 1993).

Arts for Parks -hanke sai alkunsa Nicholas Morrisin näkemyksestä, että yksiulotteinen Arts in the Parks -ajattelu ei riitä, vaan taiteen tekeminen ja kokeminen sekä kriittinen taidekasvatuksellinen toiminta tulisi sitoa kiinteäksi osaksi puistojen ympäristökasvatusta, jotta ajattelu- ja toimintatavoissa voitaisiin saavuttaa syvemmälle pureutuva muutos. Huomio pitäisi siis siirtää kokemuksellisuuteen ja nähdä oppiminen ensisijaisesti kehollisena. Oppimista syntyy, kun keho on yhteydessä ympäristöönsä (myös Anttila 2009; Foster 2016; Parviainen 1998; Rouhiainen 2011). Tarkoituksena ei siis ole vain siirtää mekaanisesti tietoja ja taitoja vaan luoda kokemuksista ja tunteista kumpuavaa yhteisen ymmärryksen tilaa (Foster ym. 2019, 136).

\footnotetext{
${ }^{1}$ Raisa Foster johti vuosina 2015-2017 Art-Eco-tutkimushanketta, jossa Satu Järvinen vastasi tutkimusapulaisena muun muassa yhdysvaltalaisen yhteistyökumppanin Nicholas Morrisin vierailusta Suomeen kesällä 2016.
} 
Yhteisön merkitys ja paikkaperustaisuus korostuvat yhdysvaltalaisen ympäristökasvatuksen tavoin myös taideperustaisessa ympäristökasvatuksessa, jota toteutetaan yhteisön kanssa sen omilla ehdoilla. Kasvattajan tärkeimmäksi tehtäväksi nousee ajan ja paikan luominen moniaististen kokemusten saavuttamiselle. Arts for Parks -kehittämishankkeessa tarkoituksena oli luoda taideperustaiselle ympäristökasvatuksen toiminnalle uudenlainen taustafilosofia puistoissa työskentelevien ympäristökasvattajien työn tueksi. Halusimme kietoa taiteen osaksi puistoissa toteutettavaa ympäristökasvatusta siten, että hyödynsimme moniammatillista yhteistyötä ympäristökasvattajien ja taiteilijoiden sekä taidekasvattajien välillä. Havainnoimme hankkeessa neljää kasvattajille suunnattua kokemuksellisuuteen ja moniaistiseen ympäristön havainnointiin keskittyvää taidetyöpajaa.

Ympäristökasvattajien haastatteluissa selvitimme ympäristökasvattajien näkemyksiä ohiolaisissa puistoissa tapahtuvasta ympäristökasvatuksesta. Kolmeen puolistukturoituun teemahaastatteluun osallistui viisi ympäristökasvattajaa: Nancy ja Linda Beech Creek Garden -puistosta, Adam Huston-Brumbaugh Nature Center -puistosta sekä Carrie ja Melinda The Wilderness Center -puistosta. Haastatteluista kaksi toteutettiin ryhmähaastatteluina ja yksi yksilöhaastatteluna. Käytämme haastateltavista heidän etunimiään, sillä he halusivat esiintyä tutkimuksessa omien puisto-organisaatioidensa edustajina omilla etunimillään. Äänitettyä haastattelumateriaalia kertyi yhteensä kuuden ja puolen tunnin verran.

Haastateltavat valikoituivat ohiolaisessa Stark Parks -puisto-organisaatiossa työskentelevän Nicholas Morrisin ehdotusten ja järjestelyiden kautta. Aineistoa analysoidessamme otammekin huomioon sen, että haastatteluihin valikoitui jo ennalta tietynlaisiin ympäristökasvatuskäytäntöihin, näkökulmiin ja arvoihin sitoutuneita henkilöitä. Emme pyri tuottamaan laajasti yleistettävää tietoa ympäristökasvattajien toiminnasta, vaan tarkastelemme tietyssä ympäristössä tapahtuvaa kasvatusta tavoitteenamme ymmärtää monipuolisesti ja syvällisesti jo pitkään ympäristökasvatusta tehneiden ammattilaisten toimintaa (ks. myös Simons 2014; Stake 2005) ja sitä kautta luomme taustafilosofiaa ja tavoitteita ympäristöinnostamiselle.

Analysoimme litteroidut aineistot laadullisen sisällönanalyysin avulla teemoittelemalla. Haastatteluaineistoa lukemalla tunnistimme toistuvia aiheita, kuten esimerkiksi kasvattajien omien lapsuusmuistojen kuvauksia. Lapsuusmuistot olivat keskenään hyvin erilaisia, mutta niitä yhdisti 
haastateltavien kuvaama merkityksellinen suhde omaan elinympäristöönsä, erityisesti luonnonympäristöihin. Aluksi pyrimme lähestymään aineistoa aineistolähtöisen sisällönanalyysin kautta, mutta pian huomasimme taustatietojen ohjaavan aineistosta esille nostamiamme ja merkityksellisinä pitämiämme teemoja. Esimerkiksi lapsuuden kokemusten merkitystä vahvan luontosuhteen muodostumisessa ovat kuvanneet myös muut tutkijat (Cantell, 2011; Kellert 2005). Ympäristökasvattajien haastatteluista oli myös alusta asti tunnistettavissa sosiokulttuurisen innostamisen piirteitä, kuten se, että innostajan täytyy itse olla innostunut voidakseen innostaa muita (Kurki 2000, 80). Tätä innostusta luontoa, yhteisöä ja opettamista kohtaan haastatellut kuvasivat toistuvasti sanalla "rakkaus" ("love"). Mikään yksittäinen teoria ei kuitenkaan viitoittanut analyysia, vaan olemme pyrkineet tarkastelemaan avoimesti ja sensitiivisesti aineistosta jäsentämiämme aiheita, kuten luontoyhteyden (uudelleen) löytämistä ja kokemuksellisuutta sekä kasvatuksen tavoitteita hyvinvoinnin lisääntymisen, luonnonympäristön arvostuksen lisääntymisen ja luonnon suojelemisen näkökulmista. Tunnistamme aikaisemman tiedon vaikutuksen (myös Tuomi \& Sarajärvi 2002, 99), ja teoreettiset kytkennät kietoutuvatkin aineistomme teemoitteluun. Pyrimme kuitenkin ennen kaikkea herättämään uusia ajatuksia jo olemassa olevan teorian testaamisen sijaan.

Haluamme tähdentää, että informantit eivät olleet "innostajia", emmekä siis kuvaa empiirisesti "ympäristöinnostamisen" toimintaa, vaan tässä artikkelissa luonnostelemamme ympäristöinnostamisen ajatus on syntynyt Arts for Parks -hankkeesta saadun aineiston analyysista sekä aiemmista sosiokulttuurisen innostamisen ja ekososiaalisen kasvatuksen teorioista johdettuna. Koemme myös, että tutkimuksemme käytännöllinen kehittämishanke ja sen analyysi sekä aiemmat innostamisen teoriat eivät kumpikaan yksinään olisi riittäneet johdattamaan meitä uudenlaisen, ekologisesti tietoisen, innostamisen mallin äärelle. Myös suomalaisen ja yhdysvaltalaisen ekologisen, sosiaalisen ja kulttuurisen näkökulman erilaisuus on tuonut kiinnostavan lisän ilmiön tarkasteluun.

\section{Luontosuhde, rakkaus ja kokemusten jakaminen}

Haastateltujen ympäristökasvattajien näkemysten sekä kokemuksellisten työpajojen observoinnin kautta löysimme kolme kasvattajia yhdistävää piirrettä: Ensinnäkin kasvattajalle on muodostunut omista kokemuksista kumpuava vastuullinen luontosuhde, jonka juuret ovat usein lapsuudessa mutta joka on voinut muodostua myös myöhemmin elämässä. Toisek- 
si kasvattaja tuntee rakkautta luontoa kohtaan eikä hän pyri peittämään tunteitaan opetustilanteessa. Rakkauden kautta esiin nousee myös tulevaisuuden toivo ja sen ylläpitäminen ja välittäminen eteenpäin. Kolmanneksi kasvattajan rakkaus ilmenee innostuksena jakaa tietoa ja tarjota kokemuksia myös muille ihmisille. Luontosuhteen, rakkauden ja kokemusten välittämisen teemat eivät suinkaan ole toisistaan irrallisia, vaikka käsittelemmekin niitä seuraavaksi erikseen.

\section{Kasvattajan omista kokemuksista nouseva luontosuhde}

Monet opettajat [ympäristökasvattajat], joihin olen törmännyt Yhdysvalloissa ja muissakin maissa, ovat kertoneet kasvaneensa joko maatilalla tai syrjäseudulla, ja he ovat halunneet jakaa muille asioita, joita rakastavat ja joista heillä oli jo aiempaa [kokemuksellista] tietoa. (Nancy)

Kasvattajien haastatteluissa korostuivat lapsuuden kokemusten merkitys. Lapsuus oli vietetty maatilalla (Nancy), lapsuudessa oli vierailtu usein puistossa (Carrie) tai käyty telttailemassa perheen kanssa (Linda). Myös haastateltujen innostus luontoa ja opettamista kohtaan kumpusi pitkälti lapsuuden kiinnostuksen kohteista ja luontokokemuksista. Kiinnostus saattoi näyttäytyä esimerkiksi harrastuksissa, joita olivat 4H-kerhon (Carrie), kesäleirien (Linda) tai partion ohjaaminen (Nancy).

Lapsuuden kokemuksista kumpuava suhde luontoon vaikutti myös myöhempiin kokemuksiin vahvasti. Nancy kertoi, kuinka yliopisto-opintojen sisällöt tuntuivat hänestä luonnollisilta, koska ne olivat linjassa hänen lapsuuden kasvuympäristönsä arvojen kanssa. Myös Adam nosti haastattelussaan esiin paikkaan sidotut juuret ja kuulumisen kokemukset.

Nancy kuvasi, että hänelle tutkintokoulutus oli vain lisenssi päästä opettamaan, sillä juuri hänen omat kokemuksensa loivat perustan toiminnalle. Haastateltavat kuvasivat, kuinka uravalinta oli usein tehty jo hyvin nuorena lapsuuden kokemusten pohjalta. Uravalintaan olivat saattaneet vaikuttaa sattumalta tapahtuneet kohtaamiset ja lapsuuden esikuvat (Linda) tai esimerkiksi ympäristön tutkimiseen ja tiedon jakamiseen kannustanut opettaja (Nancy). Carrie iloitsi siitä, että oli jo lapsena saanut tietää ympäristökasvattajan olevan oikea ammatti ja että oli tajunnut, että siinä ammatissa hänen "ei tarvitsisi koskaan kasvaa aikuiseksi": hän voisi jatkaa luonnosta nauttimista myös aikuisena.

Merkittävät lapsuuden kokemukset tai vaikkapa maatilalla vietetty lap- 
suus eivät kuitenkaan ole kasvattajuudelle välttämättömiä. Myös urbaanit ympäristöt voivat tarjota mahdollisuuden luoda tai löytää uudelleen suhde luontoon (Lumber, Richardson \& Sheffield 2017). Esimerkiksi Adam kertoi, ettei hän tiennyt, mitä haluaisi tehdä valmistumisensa jälkeen, mutta lasten opettaminen ja ulkona oleminen kuitenkin tuntuivat hyvin palkitsevilta ja veivät hänet lopulta mukanaan. Oma innostus ympäristöä kohtaan voi siis syntyä myös myöhemmin ja luoda lopulta valmiuksia innostaa myös muita.

Minulla oli hyvä työ New Yorkissa, mutta sitten tämä työtehtävä tuli auki. Olen asunut näillä seuduilla Ohiossa suurimman osan elämästäni. Elin lapsuuteni täällä ja suurin osa suvustani asuu täällä. Olin todella innoissani, kun sain mahdollisuuden aloittaa tässä työssä. Sain tulla kotiin. (Adam)

Haastateltavien kokemukset vahvistavat aiempien tutkimusten tuloksia siitä, että lapsuudella on merkittävä rooli ympäristösuhteen perustan muodostumisessa ja myös myöhemmällä iällä ympäristön hyväksi toimimisessa (Cantell 2011, 332). Toisin sanoen ympäristökasvattajan omat myönteiset lapsuuden luontokokemukset muodostavat perustan myös hänen työlleen. Toisaalta vaikka "luonto" lapsuuden elinympäristöstä puuttuisikin, voi luontosuhteen syntymistä sekä lapsuudessa että myöhemmin aikuisuudessa vahvistaa erilaisten ohjattujen harjoitteiden kautta (Kellert 2005; myös mm. Foster 2016). Joka tapauksessa luontosuhde on aina yksilöllisten kokemusten kautta muotoutunut ja subjektiivinen (Lumber ym. 2017).

\section{Kasvattajan syvä rakkaus luontoa ja yhteisöä kohtaan}

The Wilderness Center näyttää, mitä yhteisö voi saada aikaan. Tämä paikka syntyi siitä, kun joukko ihmisiä, jotka välittivät luonnosta, päättivät suojella tämän maa-alueen. Yhteisöllisyys on tärkeää. ...että on yhteisö, joka välittää. Se on kaiken ydin. (Linda)

Haastatellut kasvattajat kuvasivat tärkeitä luontokokemuksia ja kasvatuksellisia kohtaamisia syvänä rakkauden tunteena. Rakkaus näyttäytyy aineistomme valossa myös innostuksen tunteina luontoa, yhteisöä sekä tiedon jakamista kohtaan. Rakkaus on siis alkuun paneva voima, joka 
saa kasvattajat välittämään ja hoivaamaan sekä jakamaan itselleen merkityksellisiä tietoja ja kokemuksia. Melinda kuvasi ylipäätään kaikenlaisia tunteita kasvattajien työvälineiksi ja voimavaraksi, ja hän uskoi vahvasti siihen, että niitä tulisi uskaltaa käyttää ja näyttää.

Rakkautta luontoa kohtaan osoitettiin sanoin (Nancy), tai omat tunteet liitettiin puiston tärkeänä pidettyyn kasvatustehtävään (Melinda). Rakkaus saattoi näyttäytyä myös intohimona tai innostuksena sekä luontoa että opettamista kohtaan (Nancy). Rakkautta haluttiin vahvasti myös jakaa. Myös paikan historia ja siihen kuuluminen nousivat esiin rakkauden ja huolenpidon näkökulmasta. Adamille oli tärkeätä olla kotona eli lapsuudesta tutuissa ympäristöissä. Linda taas kertoi, että hänelle tärkeä puisto, joka nykyään on hänen työpaikkansa, sai alkunsa yhteisöllisyydestä, kun joukko luonnosta välittäviä ihmisiä alkoi laittaa maata "sivuun". Tämä välittämisen historia heijasteli myös hänen nykypäivän yhteisöönsä, välittävään ytimeen ja sen merkityksellisyyteen.

Kasvattajat kertoivatkin kohtaavansa työssään paljon toivoa luovia hetkiä. Carrie kertoi, että hän näkee työssään yhä uudelleen ja uudelleen, että luonnosta huolehtiminen lisää ihmisten omaa hyvinvointia - ihmiset löytävät uudelleen yhteyden luontoon ja sen myötä uuden suunnan myös omalle elämälleen. Hän kertoi saaneensa toivoa erityisesti siitä, että hän oli huomannut milleniaalien, eli 2000-luvun alkupuoliskolla täysi-ikäiseksi tulleiden aikuisten, hakeutuvan luontoon yhä enemmän.

Melinda taas kuvasi pieniä arjessa näyttäytyviä merkityksellisiä kokemuksia esimerkiksi perhostalon kautta, jossa vanhukset, autismikirjon lapset tai "tavallisesti vain puhelimiaan tuijottavat nuoret" ovat kokeneet voimakkaita elämyksiä saadessaan katsella perhosia lähietäisyydeltä. Melinda kertoi vanhuksista, jotka istuivat pyörätuoleissa eivätkä kyenneet juurikaan reagoimaan ympäröivään maailmaan. Melinda otti sokeriveteen kastetun pumpulipuikon, jolle perhonen laskeutui ja vei sen lähelle vanhuksen kasvoja. Vanhuksen kasvot kirkastuivat ja hän pystyi pienen hetken olemaan vuorovaikutuksessa ympäristönsä kanssa. Melinda jatkoi: "Väristykset kulkivat kehoni läpi. Silmiini kertyi kyyneleitä ja vanhusten kanssa työskentelevät näkivät, mitä tein. He näkivät reaktion ja he kaikki alkoivat tehdä samoin.”

Haastattelemamme ympäristökasvattajat olivat huolissaan ihmisten ja erityisesti lasten eriytymisestä luonnosta (myös Louv 2005; Soga \& Gaston 2016), mutta heidän puhuessaan rakkaudesta nousi esiin toivo tulevaisuuden suhteen (myös Ojala 2015). Värrin $(2018,12)$ mukaan kasvatus ja toi- 
vo kuuluvatkin läheisesti yhteen. Myös Panu Pihkala $(2017,143)$ korostaa toivon merkitystä elämän mielekkyyden ylläpitäjänä. Ympäristökasvattaja löytää siis nimenomaan rakkauden kautta toivon ja syvän viisauden sekä yhteyden paitsi toisiin ihmisiin myös enemmän kuin ihmisen maailmaan (Abram 1996).

Rakkautta ei pidä ympäristökasvatuksen kontekstissa ymmärtää kapeasti "romanttisena" tunteena, vaan Frommin (1976) tapaan elämää keskeisesti ylläpitävänä voimana. Elämänvoimassa, eli biofiliassa (myös Kellert \& Wilson 1993; Wilson 1984) rakkaus kietoutuu kokemukseen ja järkeen: "Biofilia on intohimoista elämän ja kaiken elollisen rakastamista, se on halua edistää kasvua, oli kyse sitten ihmisestä, kasvista, ajatuksesta tai sosiaalisesta ryhmästä" (Fromm 1976, 431). Martusewicz (2019, 166-168) puhuu eroksesta, "maasta kumpuavasta viisaudesta" (engl. earth-bound wisdom), joka tarkoittaa kehollista yhteyttämme luontoon (ks. myös Foster 2016; Värri 2018) ja joka kutsuu meitä suojelemaan ja hoivaamaan sitä. Erokseen sisältyy myös selkeä käsitys paikasta ja kuulumisesta sekä pyrkimys yhteyteen toisten ihmisten ja muun maailman kanssa (Martusewicz $2019,168)$.

\section{Kasvattajan innostus tiedon jakamiseen ja kokemusten tarjoamiseen}

Omat tunteeni ovat täysin linjassa puistomme tavoitteiden kanssa. Uskon vakaasti, että jos saamme ihmiset ulos ja luomaan yhteyden luontoon, kasveihin, ympäristöön ja eläimiin, heille muodostuu syvempi arvostus luontoa kohtaan. He ymmärtävät, että meidän täytyy suojella sitä, jotta meillä olisi terveellinen ympäristö. Kun he menevät elämässään eteenpäin, he alkavat tehdä parempia elämänvalintoja ja sitä myöden heidän elämänlaatunsa paranee. Tähän minä uskon ja tämä vie minua eteenpäin. Uskon, että kaikki on yhteydessä toisiinsa ja että autamme luontoa innostamalla ihmisiä. (Melinda)

Haastatteluissa nousi esiin erityisesti halu tietojen ja luontokokemusten jakamiseen. Puistoissa kasvattajan työ on siis innostamista kokemusten äärelle, jolloin tietojen opettaminen ei ole ensisijaisessa asemassa, kuten Linda nosti esiin: "Oleellista ei ole niinkään jakaa faktoja. Kyse on enemmän kokemuksesta." "Opin paljon lapsilta, usein yksinkertaisesti heidän kysymystensä kautta”, Adam kertoi. Myöskään hänen mielestään keskeistä ei ole opettaa yksityiskohtaista tietoa, vaan näyttää, kuinka luonnonympä- 
ristöön voi olla vuorovaikutuksessa ja tutkia sitä. Adamin mukaan nimenomaan aistimisen, katselemisen ja kuuntelemisen kautta ihmiset osallistuvat sitoutuneesti.

Myös aikuisten kanssa ympäristökasvatuksessa keskeistä on kokemuksellisuus. Carrie kuvasi sitä, kuinka aikuisia tulee ensisijaisesti muistutella siitä ilosta, mikä heillä lapsuudessa oli. Aikuiset eivät useinkaan käytä kaikkia aistejaan ja siksi he menettävät kyvyn huomata laajasti asioita ympäristössään. "He ovat niin tottuneita keskittymään vain yhteen asiaan", Carrie huomautti. Carrielle ympäristökasvatuskohtaamisissa keskeistä on "rauhoittuminen, ympärilleen katsominen ja uudelleen tutustuminen luontoon tavalla, jota he rakastivat lapsina".

Haastatteluiden lisäksi myös työpajoihin osallistuneet kasvattajat toivat ilmi, miten esimerkiksi kenkien ottaminen pois ulkona tuntui osallistujista jopa radikaalilta teolta. Lopulta kuitenkin kävely nurmikolla tuntui luonnolliselta ja nostatti kasvattajien mieleen muistoja lapsuudesta. Polulla ryhmän ohitse luikerteli käärme, joka herätti osallistujissa suurta kiinnostusta ja eräs osallistujista nosti yllättäen käärmeen käsiinsä. Kokemuksen jälkeisessä reflektiossa puhuttiin siitä, kuinka aiemmat pelot ja tarve hallita luontoa ja tapahtunutta, väistyivät. Syntyi kokemus yhteisesti jaetusta hetkestä.

Aististen ja kokemuksellisten havaintojen lisäksi ympäristönsuojeluun ja ekokriisin ratkaisuun liittyvät teemat nousivat myös vahvasti esille haastatteluissa:

Aikuisille on tärkeää, nyt ehkä enemmän kuin koskaan meidän kotimaassamme, antaa ihmisille hyvä [luonto]yhteys, jotta he voivat alkaa välittää uudelleen; mutta myös antaa heille taustatietoa, jotta he voisivat ymmärtää todella monimutkaista tutkimustietoa siitä, mitä nyt on meneillään. Ilmastonmuutos, lajikato ja elinympäristöjen suojeleminen, pirstaloituminen ja kaikki nuo ongelmat. Me voimme antaa hyvän taustan, johon nojata, kun he yrittävät selvittää, mitä he kuulevat uutisissa tai lukevat artikkeleissa. Minun mielestäni meidän maamme [Yhdysvallat] erityisesti tarvitsee sitä enemmän kuin koskaan: hyvän pohjan, jonka kautta voi arvioida, mikä on tiedettä ja mikä ei ole tiedettä. Sekä myös oppia katsomaan kriittisesti ja ymmärtää hieman taustaa. Joten kaiken kaikkiaan he voivat käyttää oppimaansa tietoa siihen, miten ottaa selvää [asioista]. (Carrie) 
Pelkän tiedon jakamisen sijaan haastatellut kasvattajat kertoivat erityisesti auttavansa, innostavansa ja inspiroivansa ihmisiä kohti kokemuksellista suhdetta luontoon. Tämä kuitenkin onnistuu vain, jos innostaja on itse innostunut (Foster 2015, 21; Kurki 2000, 80), kuten myös haastateltavamme Linda totesi: "Lapset ovat innostuneita, koska minä olen innostunut".

Ympäristökasvattajan työtä voi ensisijaisesti kuvata moninaisten ilmiöiden tutkimiseksi erilaisten ihmisten ja ryhmien kanssa. Kasvattajan ei siis tarvitse, eikä hän voikaan, tietää kaikkia vastauksia. Sen vuoksi kasvattajan on heittäydyttävä tutkimaan maailmaa aina yhdessä kasvatettavien kanssa (Freire 2005, 80) ja synnytettävä näin yhteistä ymmärrystä ammentaen paitsi kognitiivisesta tiedosta myös kokemuksista ja tunteista (Foster ym. 2019). Kokemuksellisuudessa korostuvat yhteyksien luominen, merkityksellisyys, myötätunto ja kauneus (Lumber, Richardson \& Sheffield 2017, 21). Obery ja Bangert (2017) ovat myös havainneet, että innostus jakaa luontokokemuksia on yhteydessä siihen, miten ihminen sitoutuu ympäristönsuojeluun. Ekokriisin aikana ympäristöinnostamisen perimmäinen tavoite on kannustaa toimintaan ympäristön suojelemiseksi.

\section{Kohti ympäristöinnostamista}

Ekokriisin aiheuttaman ekologisen muutostarpeen myötä tarvitaan eettistä toimintakykyä ja yhteistyötä ihmisten ja yhteisöjen välillä enemmän kuin koskaan ennen (Värri 2018, 123). Arts for Parks -hankkeessa tehdyissä haastatteluissa nousi esiin ympäristökasvattajien pitkäjänteinen työ oman lähiympäristön ja yhteisön hyvinvoinnin lisäämiseksi. Havaintojemme mukaan vaikuttavan ympäristökasvatuksen taustalla on nähtävissä kolme piirrettä: 1) merkitykselliset kokemukset luonnosta lapsuudessa tai myöhemmin elämässä, 2) rakkaus luontoa, paikkaa ja yhteisöä kohtaan sekä 3) innostus tiedon ja kokemusten jakamiseen. Nämä piirteet ovat myös linjassa sosiokulttuurisen innostamisen ominaispiirteiden kanssa.

Sosiokulttuurinen innostaminen on vain yksi innostamisen osa-alue. Innostamisen tarkempi luokittelu voi auttaa kuvaamaan paremmin toiminnan sisältöä (Kurki 2000, 21). Ekokriisin aikakaudella ekososiokulttuurisen näkökulman esille nostaminen on perusteltua, mutta käsitteenä ekososiokultturinen innostaminen olisi kömpelö, joten käytämme nimitystä ympäristöinnostaminen. Ympäristöinnostamisen lähtökohtana on sen hahmottaminen, että ekologinen kriisi on pohjimmiltaan kulttuuri- 
nen kriisi ja tapamme toimia muiden ihmisten ja eläinten kanssa linkittyy vahvasti ympäristökäyttäytymiseemme (Martusewicz ym. 2015, 10).

Ympäristöinnostamisen keskeisimpänä tehtävänä on ohjata kohti ekososiaalista sivistystä eli auttaa innostettavaa sisäistämään ihmisen erottamaton yhteys muuhun elämään. Siksi ehdotamme ympäristöinnostamisen toiminnan tavoitteeksi nimenomaan ohjaamista 1) emansipaatioon eli vapautumaan ekososiaalisesti haitallisista arvoista ja asenteista ja sitä kautta ympäristölle ja ihmiselle tuhoisasta toiminnasta. Ympäristöinnostajan tulee toimia luontokokemusten ja kestävän vuorovaikutuksen 2) välittäjänä siten, että osallistuja havahtuu vastuulliseen luontosuhteeseen. Vaikuttavan ympäristöinnostamisen toiminnan edellytyksenä näemme innostajan 3) henkilökohtaisen työotteen ja 4) paikkasidonnaisen ymmärryksen.

Innostamisessa on aina ollut kyse pedagogisen tiedostamisen, sosiaalisen luovuuden ja osallistumisen liikkeestä, jossa tärkeään osaan on noussut myös emansipaatio (Kurki 2000, 11; myös Freire 2005). Emansipaatio on myös ympäristökysymyksiä käsiteltäessä ensisijaista, sillä meidän tulee vapautua niistä ympäristölle haitallisista toimintatavoista, joita usein vain toisinnamme kasvatuksen ja sosialisaation kautta (Foster ym. 2019; Martusewicz ym. 2015; Värri 2018). Innostamisen keskeinen tavoite on saada ihmiset huomaamaan, että heidän valintansa ja toimintansa ovat kytköksissä yhteisölliseen ja yhteiskunnalliseen toimintaan mutta myös elinympäristöön ja sen ekologiseen ulottuvuuteen.

Kurki $(2000,56)$ nostaa innostamisen erityistehtäväksi ilmaista sellaisia tavoitteita, jotka heijastavat, millainen tulevaisuuden tulisi olla. Ympäristöinnostamisen keskeisenä tavoitteena on luoda ihmisten oman osallistumisen avulla ekososiaaliset arvot tiedostavaa yhteiskuntaa (ks. myös Kurki 2000, 14). Salosen ja Bardyn $(2015,7)$ mukaan: "Ihminen, joka ottaa vastuuta toisesta ihmisestä, ottaa todennäköisesti vastuuta myös luonnosta - ja päinvastoin.” Tämä tarkoittaa sitä, että ympäristöinnostajan tulisi pyrkiä herättelemään sekä ihmisten keskinäistä että ihmisen ja luonnon välistä vastuullisuutta sekä ylläpitää toivoa ekososiaalisesti kestävän tulevaisuuden suhteen (myös Foster ym. 2019). Ympäristöinnostamisen perimmäisenä tarkoituksena on vapauttaa ihmiset ekososiaalisen välinpitämättömyyden ja ongelmien sivuuttamisen ilmapiiristä kohti toimintaa ja yhteiskunnallista muutosta (myös Kurki 2000, 56-57; 2005, 352).

Ympäristöinnostaja toimii tunteiden, tietojen ja kokemusten välittäjänä ja tulkitsijana (interpreter) rohkaisten ihmisiä kriittiseen ajatteluun 
ja ottamaan vastuuta oman elinpiirinsä hyvinvoinnista. Ympäristökasvatuksen konseptissa välittämistä (interpretation) voidaan pitää vuorovaikutuksellisena prosessina (Hvenegaard, Shultis \& Butler 2009, 202), jonka tarkoituksena on paljastaa luonnon ja kulttuurin merkityksiä ja suhteita ihmisille erityisesti omakohtaisen osallistumisen kautta (Tilden 1957, 8). Välittäjä ei toimi opettajana, vaan hänen tarkoituksenaan on vaikuttaa ja saada muutosta ihmisten tavoissa ja näkökulmissa (Ham \& Krumpe 1996, 12-13). Välittämisessä lähdetään ensisijaisesti kokemuksista eikä niinkään tiedon jakamisesta (Mullins 1984, 1).

Välittämisessä korostuu tietyn ryhmän tai yhteisön merkitys ja heidän ajattelu- ja toimintatapoihinsa suuntautuva muutos, jotta he voisivat löytää kestävämpiä tapoja olla vuorovaikutuksessa lähiympäristönsä kanssa. Kestävä tulevaisuus edellyttää vastuullista luontosuhdetta, mutta on kuitenkin tärkeätä tiedostaa, ettei ole olemassa yhtä "oikeaa" luontosuhdetta (Kellert 1993; Kellert \& Wilson 1993; Mayer \& Franz 2004). Ympäristöinnostajan tulee siis ymmärtää, ettei "luontosuhde" tarkoita jotakin neutraalia, kaikille ihmisille samalla tavalla näyttäytyvää ilmiötä, vaan se voi olla vaikkapa esteettiseen elämykseen tai terveyshyötyihin tähtäävää tai kytkeytyä esimerkiksi metsästykseen tai kalastukseen harrastuksena tai elinkeinona. Yksilö saattaa siis liittää positiivisia tuntemuksia luonnossa oleiluun, mutta silti ihmisen suhde luontoon voi perustua ajatukseen, että luonto olisi jotakin ihmisestä täysin irrallista ja nimenomaan vain ihmisen hyötyä palvelevaa (Nurmio 2000). Ympäristöinnostamisella pyritään kestävän ja vastuullisen luontosuhteen muodostumiseen: sen perimmäisenä tavoitteena on irtautua välinearvoisesta suhtautumisesta luontoon ja ymmärtää, että ihminen on myös itse erottamaton osa luontoa.

Haastattelemiemme ympäristökasvattajien mukaan kasvatuskohtaamisiin liittyy omakohtaisten merkityksellisten kokemusten kautta syvä henkilökohtainen ulottuvuus, johon toiminnan keskeisin sisältö kytkeytyy (myös Kurki 2000, 20). Koska ympäristöinnostaminen liikkuu kasvatuksellisen, yhteiskunnallisen ja ekologisen tiedon alueilla, on selvää, ettei innostaja voi olla asiantuntija kaikilla näillä tiedon aloilla. Ympäristöinnostajan tulee arvostaa omaa kokemustaan ja pyrkiä sitä kautta innostamaan ja luomaan merkityksellisiä luontokokemuksia myös toisille ihmisille.

Perinteisesti opettajia on käsketty pitämään tunteet pois opetustyöstä, mutta sekä innostamisen teorian että käytännön havaintojemme valossa kehotamme kasvattajia päinvastoin tunnistamaan itsensä ei vain tiedollisina vaan myös tuntevina olentoina. Asiakeskeisen osaamisen rinnalle 
tarvitaan siis myös "tunnetason yhteyttä, tunteiden jakamista ja kiintymyksen sallimista sosiaalipedagogisissa suhteissa" (Nivala \& Ryynänen $2019,191)$. Näin innostaja voi löytää omasta persoonastaan tärkeän voimavaran ja työkalun innostamisen toimintaan (Kurki 2000, 20). Ympäristöinnostajan oma rakkaus kaikkea elävää kohtaan luo pohjan toiminnalle, kuten myös Rebecca Martusewicz $(2019,167)$ on kuvannut:

"[T]äällä [lapsuuden ympäristössä] muotoutui sydämeni ja sieluni, ensikosketukseni syvään yhteyteen oikeudenmukaisuuden kanssa, rakkauteni maailmaan ja päätökseni opettaa kärsimystä vastaan.”

Innostajalla tulee olla vastuullisuutta, luovuutta ja tutkimuksellista otetta, kykyä itsekriittisyyteen ja tahtoa täyttää antamansa lupaukset (Kurki 2000, 81). On siis tärkeätä, että ympäristöinnostaja reflektoi myös kriittisesti esimerkiksi omaa luontosuhdettaan ja ymmärtää sen vaikutuksen hänen kasvatustyönsä arvopohjaan, valintoihin ja käytännön ratkaisuihin. Innostaja ei välttämättä jaa samanlaista luontosuhdetta osallistujien kanssa. Hänen tulee kuitenkin olla joustava ja pystyä tarvittaessa muuttamaan myös omaa näkökulmaansa (Kurki 2000, 8). Keskeistä on muistaa, että innostamista tulee tehdä aina yhteisöstä käsin. Siksi innostajan onkin asetuttava dialogiin yhteisönsä kanssa ja sallittava avoin keskustelu erilaisista näkökulmista ja pyrkimyksistä.

Sekä yhdysvaltalaisessa ympäristökasvatuksessa että sosiokulttuurisessa innostamisessa korostuu yhteisön hyvä tunteminen sekä yhteisön jäsenten arvojen ja ongelmallisten käyttäytymismallien tunnistaminen (Ham \& Krumpe 1996, 12-13). Ympäristöinnostajan toiminta on siis aina paikallisesti juurtunutta, eli innostajan tulee tutustua perusteellisesti siihen yhteisöön, jonka kanssa hän työskentelee (Kurki 2000, 32; myös Nivala \& Ryynänen 2019). Ympäristöinnostaminen ei siis missään nimessä tarkoita sitä, että innostaja vain piipahtaa itselleen sosiaalisesti, kulttuurisesti ja ekologisesti oudossa ympäristössä tekemässä pinnallisia "puunhalausharjoitteita" satunnaisten osallistujien kanssa. Ympäristöinnostaminen on pitkäjänteistä ja määrätietoista työtä kohti yhteisesti parempaa tulevaisuutta. Ympäristöinnostajalle "parempi tulevaisuus" on ekososiaalisesti kestävä ja edellyttää yksilöiden vastuullisen luontosuhteen muodostumista.

Arts for Parks -hanke keskittyi nimenomaan taiteellisen kokemuksen ja puistoissa tapahtuvan ympäristökasvatuksen yhdistämiseen. Oleellista on 
se, ettei taidetta tuoda luontoon ikään kuin koristamaan ympäristöä vaan että yhteisö omaksuu "taiteellisen asenteen" eli toisin sanoen aistimellisen ja kokemuksellisen suhteen ympäristön havainnointiin (myös Foster 2016; Foster ym. 2019). Arts for Parks -ajatuksen mukaista taideperustaista ympäristökasvatusta tehdään aina yhteisön ehdoilla ja yhteisön kanssa. Niinpä mallin mukaista toimintaa voi luontevasti toteuttaa myös Suomessa. Tärkein tehtävä on luoda tila ja paikka moniaistisille kokemuksille.

Vaikka taidenäkökulma on ollut tutkimuksessamme mukana koko ajan, emme ole tarkastelleet taidenäkökulmaa tässä artikkelissa. Näkemyksemme mukaan ympäristöinnostaminen voi sisältää erilaisia taiteellisia aktiviteetteja. Taiteellinen asenne ja kokemusperäinen oppiminen linkittyvät molemmat kokonaisvaltaisen ympäristöinnostamisen ideaan, joka asettuu vastavoimaksi dualistiselle, ihmisen ja luonnon jyrkästi erottavalle, maailmankuvalle. Ympäristöinnostamisen voima on nykytaidekasvatuksen tapaan sen pyrkimyksessä "toisintekemiseen" (Foster 2017), mikä edellyttää emansipaatiota haitallisista arvoista, asenteista ja tavoista mutta myös kykyä kuvitella uudenlaisia, kestävämpiä toimintamuotoja.

\section{Lopuksi}

Tämän tutkimuksen lähtökohtana olivat oppimiskokemuksemme yhdysvaltalaisissa puistoissa tapahtuvasta ympäristökasvatuksesta. Arts for Parks -hankkeen haastattelu- ja havainnointiaineistosta teemoittelimme vaikuttavan ympäristökasvatuksen keskeiset piirteet, joita olivat kasvattajan omista kokemuksista nouseva vastuullinen luontosuhde ja syvä rakkaus luontoon sekä innostus tiedon jakamiseen ja kokemusten tarjoamiseen. Hankkeen pohjalta luonnostelimme edelleen ympäristöinnostamisen lähtökohdat sosiokulttuurisen innostamisen teoriapohjaan nojaten.

Ympäristöinnostaminen on paikkasidonnaista ja ote on toimintatutkimuksellinen. Työtä määrittää henkilökohtainen ote, eli ympäristöinnostajan tulee omaa kokemustaustaansa hyödyntäen ja rakkaudesta ammentaen toimia aktiivisesti yhteisönsä hyväksi mahdollistamalla myös muille merkityksellisiä luontokokemuksia. Ympäristöinnostaja ei siis ensisijaisesti ole ympäristö- ja luonnontiedon opettaja, vaan merkitysten ja suhteiden välittäjä, eli toisin sanoen innostamisen aktiviteettien ja niistä syntyneiden tunteiden ja kokemusten kautta vahvistuvan vastuullisen luontosuhteen mahdollistaja. Ympäristöinnostajan tulee tunnistaa innostamisen kohteena olevien ihmisten elämismaailman olosuhteet ja ohjata emansipaatioon kestämättömyyttä tuottavista arvoista ja rakenteista. 
Ympäristöinnostajan tehtävänä on kannustaa yhteisöä kohti ekologisesti ja sosiaalisesti kestävämpää tulevaisuutta. Ympäristöinnostamisen kautta voimme elähdyttää yksilöitä ja yhteisöjä sekä saada aikaan toimintaa sekä ihmisyhteisön että ekosysteemin hyväksi.

\section{LÄHTEET}

Aarnio-Linnanvuori, E. 2019. How do teachers perceive environmental responsibility? Environmental Education Research 25(1), 46-61. Saatavissa https://doi.org/10.1080/ 13504622.2018.1506910 (haettu 18.8.2020).

Abram, D. 1996. The spell of the sensuous: Perceptions in a more-than-human world. New York: Random House.

Alhanen, K. 2013. John Deweyn kokemusfilosofia. Helsinki: Gaudeamus.

Andrews, E., Stevens, M. \& Wise, G. 2002. A model of community-based environmental education. Teoksessa T. Dietz \& P. C. Stern (eds.) New tools for environmental protection: Education, information, and voluntary measures. Washington DC: National Academy Press, 161-182.

Anttila, E. 2009. Mitä tanssija tietää? - Kehollinen tieto ajattelun ja oppimisen perustana. Aikuiskasvatus 29 (2), 84-92.

Berleant, A. 2006. Mitä on ympäristöestetiikka? Teoksessa A. Haapala, M. Honkanen \& V. Rantala (toim.) Ympäristö, arkkitehtuuri, estetiikka. Helsinki: Helsinki University Press, 87-114.

Cantell, H. (toim.) 2004. Ympäristökasvatuksen käsikirja. Jyväskylä: PS-kustannus.

Cantell, H. 2011. Lapsuus ja nuoruus ympäristösuhteen perustana. Teoksessa J. Niemelä, E. Furman, A. Halkka, E. Hallanaro \& S. Sorvari (toim.) Ihminen ja ympäristö. Helsinki: Gaudeamus, 332-338.

Cantell, H., Aarnio-Linnanvuori, E. \& Tani, S. 2020. Ympäristökasvatus: Kestävän tulevaisuuden käsikirja. Jyväskylä: PS-kustannus.

Cantell, H., Tolppanen, S., Aarnio-Linnanvuori, E. \& Lehtonen, A. 2019. Bicycle model on climate change education: presenting and evaluating a model. Environmental Education Research 25 (5), 717-731.

Carter, R.L. \& Simmons, B. 2010. The History and Philosophy of Environmental Education. Teoksessa A. Bodzin, B. Shiner Klein \& S. Weaver (eds.) The Inclusion of Environmental Education in Science Teacher Education. Dordrecht: Springer.

Foster, R. 2012. The Pedagogy of Recognition - Dancing Identity and Mutuality. Väitöskirja. Tampere: Tampere University Press.

Foster, R. 2015. Tanssi-innostaminen: Kohti yksilön ja yhteisön hyvinvointia. Helsinki: Books on Demand.

Foster, R. 2016. Hiljainen kosketus - kohti ekofilosofista kasvatusta. Teoksessa A. Suominen (toim.) Taidekasvatus ympäristöhuolen aikakaudella - avauksia, suuntia, mahdollisuuksia. Helsinki: Aalto ARTS Books, 165-175. 
Foster, R. 2017. Nykytaidekasvatus toisintekemisenä ekososiaalisten kriisien aikakaudella. Sosiaalipedagogiikan aikakauskirja 18, 35-56.

Foster, R., Salonen, A. \& Keto, S. 2019. Kestävyystietoinen elämänorientaatio pedagogisena päämääränä. Teoksessa T. Autio, L. Hakala ja T. Kujala (toim.) Siirtymiä ja ajan merkkejä koulutuksessa: Opetussuunnitelmatutkimuksen näkökulmia. Tampere: Tampere University Press, 121-143.

Freire, P. 2005. Sorrettujen pedagogiikka. Tampere: Vastapaino.

Fromm, E. 1976. Tuhoava ihminen. Helsinki: Kirjayhtymä.

Ham, S. \& Krumpe, E. 1996. Identifying Audiences and Messages for Nonformal Environmental Education - A Theoretical Framework for Interpreters. Journal of Interpretation Research 1 (1), 11-23.

Homer-Dixon, T. 2006. The Upside of Down: Catastrophe. Creativity and the Renewal of Civilisation. Washington: Island Press.

Hvenegaard, G., Shultis, J. \& Butler, J. 2009. The role of interpretation. Teoksessa P. Dearden \& R. Rollins (eds.) Parks and Protected Areas in Canada: Planning and Management. Don Mills, ON: Oxford University Press, 202-234.

Jokisaari, O-J. 2014. Tapausfilosofia kasvatuksen aikalaiskritiikkinä: edistyksen mahdollisuus nykyisyydessä. Teoksessa A. Saari, O-J. Jokisaari \& V-M. Värri (toim.) Ajan kasvatus. Kasvatusfilosofia aikalaiskritiikkinä. Tampere: Tampere University Press, 23-40.

Kellert, S. R. 1993. Attitudes, knowledge, and behavior toward wildlife among the industrial superpowers: United States, Japan, and Germany. Journal of Social Issues 49, 53-69.

Kellert, S. R. 2005. Building for Life: Designing and Understanding the Human-Nature Connection. Washington: Island Press.

Kellert, S. R. \& Wilson, E. O. (eds.) 1993. The biophilia hypothesis. Washington: Island Press.

Kudryavtsev, A., Stedman, R. C. \& Krasny, M. E. 2012. Sense of place in environmental education. Environmental Education Research 18 (2), 229-250.

Kurki, L. 2000. Sosiokulttuurinen innostaminen: Muutoksen pedagogiikka. Tampere: Vastapaino.

Kurki, L. 2005. Sosiokulttuurinen innostaminen yhteisöllisyyden rakentajana. Teoksessa T. Kiilakoski, T. Tomperi \& M. Vuorikoski (toim.) Kenen kasvatus? Kriittinen pedagogiikka ja toisinkasvatuksen mahdollisuus. Tampere: Vastapaino, 335-357.

Kurki, L. 2010. Sosiokulttuurinen innostaminen vankilassa. Teoksessa L. Kurki, M. KurkiSuutarinen \& K. Taruvuori (toim.) Muurien sisällä: Sosiokulttuurinen innostaminen vankilassa. Tampere: Tampere University Press, 133-212.

Louv, R. 2005. Last Child in the Woods: Saving Our Children from NatureDeficit Disorder. Chapel Hill, NC: Algonquin Books.

Lumber, R., Richardson, M. \& Sheffield, D. 2017. Beyond knowing nature: Contact, emotion, compassion, meaning, and beauty are pathways to nature connection. PloS one 12 (5), e0177186. 
Martusewicz, R., Edmundson, J. \& Lupinacci, J. 2015. EcoJustice Education: Toward Diverse, Democratic and Sustainable Communities. New York: Routledge.

Martusewicz, R. 2019. Love in the Commons: Eros, Eco-Ethical Education, and a Poetics of Place. Teoksessa R. Foster, J. Mäkelä \& R. Martusewicz (eds.) Art, Ecojustice, and Education. Intersecting Theories and Practices. New York: Routledge, 166-177.

Matthies, J. 2001. Luonto pedagogisena ohjelmana? - luonnon mystifioinnin vaarasta ympäristökasvatuksessa. Niin \& Näin 8 (2), 36-44.

Mayer, F. S. \& Frantz, C. M. 2004. The connectedness to nature scale: A measure of individuals' feeling in community with nature. Journal of Environmental Psychology 24 (4), 503-515.

Mullins, G. 1984. The Changing Role of the Interpreter. The Journal of Environmental Education 15 (4), 1-5.

Nivala, E. \& Ryynänen, S. 2019. Sosiaalipedagogiikka. Kohti inhimillisempää yhteiskuntaa. Helsinki: Gaudeamus.

NPS 2020. National Park Service. Saatavissa: https://www.nps.gov/index.htm (haettu 17.2.2020).

Nurmio, H. 2000. Luonnon itseisarvon ja välinearvon dilemma. Niin \& Näin 7 (3), 18-26.

Obery, A., \& Bangert, A. 2017. Exploring the Influence of Nature Relatedness and Perceived Science Knowledge on Proenvironmental Behavior. Education Sciences 7 (1). Saatavissa https://doi.org/10.3390/educsci7010017 (haettu 27.1.2020).

Ojala, M. 2015. Hope in the Face of Climate Change: Associations With Environmental Engagement and Student Perceptions of Teachers' Emotion Communication Style and Future Orientation. The Journal of Environmental Education 46 (3), 133-148. Saatavissa https://doi.org/10.1080/00958964.2015.1021662 (haettu 18.8.2020).

Parikka-Nihti, M. \& Suomela, L. 2014. Iloa ja ihmettelyä: Ympäristökasvatus varhaislapsuudessa. Jyväskylä: PS-kustannus.

Parviainen, J. 1998. Bodies moving and being moved: a Phenomenological Analysis of the Dancing Subject and the Cognitive and Ethical values of Dance Art. Tampere: Tampere University Press.

Piguet, E. 2013. From "Primitive Migration" to "Climate Refugees": The Curious Fate of the Natural Environment in Migration Studies. Annals of the Association of American Geographers 103 (1), 148-162.

Pihkala, P. 2017. Päin helvettiä? Ympäristöahdistus ja toivo. Helsinki: Kirjapaja.

Plumwood, V. 2002. Environmental Culture: The Ecological Crisis of Reason. New York: Routledge.

Pohjakallio, P. 2016. Ympäristö, kasvatus, taide - avoimia ja muuttuvia käsitteitä kuvataideopettaja-koulutuksessa. Teoksessa A. Suominen (toim.) Taidekasvatus ympäristöhuolen aikakaudella - avauksia, suuntia, mahdollisuuksia. Helsinki: Aalto ARTS Books, 56-68.

Rouhiainen, L. 2011. Fenomenologinen näkemys oppimisesta taiteen kontekstissa. Teoksessa E. Anttila (toim.) Taiteen jälki: Taidepedagogiikan polkuja ja risteyksiä. Helsinki: Teatterikorkeakoulu, 75-94. 
Saari, A. 2016. Elinikäinen oppiminen ja yksilöivä valta. Aikuiskasvatus 36 (1), 4-11.

Salonen, A. 2014. Ekososiaalinen hyvinvointiparadigma - yhteiskunnallisen ajattelun ja toiminnan uusi suunta täyttyvällä maapallolla. Sosiaalipedagoginen aikakauskirja 15 , $32-62$.

Salonen, A. \& Bardy, M. 2015. Ekososiaalinen sivistys herättää luottamusta tulevaisuuteen. Aikuiskasvatus 35 (1), 4-15.

Salonen, A. \& Konkka, J. 2015. An Ecosocial Approach to Well-Being: A Solution to the Wicked Problems in the Era of Anthropocene. Foro de Educación 13 (19), 19-34.

Sava, I. 1993. Taiteellinen oppimisprosessi. Teoksessa I. Porna \& P. Väyrynen (toim.) Taiteen perusopetuksen käsikirja. Helsinki: Suomen Kuntaliitto, 15-43.

Simons, H. 2014. Case Study Research: In-Depth Understanding in Context. Teoksessa P. Leavy (ed.) The Oxford Handbook of Qualitative Research. New York: Oxford University Press, 455-470.

Soga, M. \& Gaston, K. J. 2016. Extinction of experience: the loss of human-nature interactions. Frontiers in Ecology and the Environment 14 (2), 94-101. Saatavissa https://doi.org/10.1002/fee.1225 (haettu 27.1.2020).

Stage, F. K., \& Dannells, M. (eds.) 2000. Linking theory to practice: Case studies for working with college students. New York: Brunner-Routledge.

Stake, R. E. 2005. Qualitative Case Studies. Teoksessa N. K. Denzin \& Y. S. Lincoln (eds.) The Sage handbook of qualitative research. Thousand Oaks, CA: Sage Publications, 443-466.

Stevenson, R. B. 2007. Schooling and environmental education: contradictions in purpose and practice. Environmental Education Research 13 (2), 139-153.

Suominen, A. 2016. Johdanto. Teoksessa A. Suominen (toim.) Taidekasvatus ympäristöhuolen aikakaudella - avauksia, suuntia, mahdollisuuksia. Helsinki: Aalto ARTS Books, 8-19.

Tilden, F. 1957. Interpreting our heritage. Chapel Hill: University of North Carolina Press.

Tuomi, J. \& Sarajärvi, A. 2002. Laadullinen tutkimus ja sisällönanalyysi. Helsinki: Tammi.

Valkonen, J. 2013. Johdanto. Teoksessa J. Valkonen \& T. Salonen (toim.) Reittejä luontosuhteeseen. Rovaniemi: Lapland University Press, 5-12.

Värri, V-M. 2007. Kasvatusfilosofian tärkein tehtävä. Niin \& Näin 14 (1), 70-73.

Värri, V-M. 2018. Kasvatus ekokriisin aikakaudella. Tampere: Vastapaino.

Wilson, E. O. 1984. Biophilia. Cambridge MA: Harvard University Press.

Woodhouse, J. L. \& Knapp, C. 2000. Place-based curriculum and instruction: outdoor and environmental education approaches. Charleston, WV: Clearinghouse on Rural Education and Small Schools, Appalachia Educational Laboratory. 